Kinga Stopczyńska

\title{
Wykorzystanie działań Corporate Social Responsibility (CSR) w kreowaniu lojalności klienta
}

\section{Wstęp}

Przed firmami funkcjonującymi na dzisiejszym rynku stoi wiele wyzwań związanych z dynamiką zmian, jakie na nim zachodzą. Z jednej strony rosnące oczekiwania klienta, z drugiej wymagający rynek partnerów biznesowych powodują, iż każdy dzień niesie za sobą wymagania, które dla wielu podmiotów są bardzo trudne do spełnienia, często wręcz niestety niemożliwe. Jednak są firmy, które od samego początku swojego funkcjonowania skupione są na stworzeniu strategii wymagających od nich pełnego zaangażowania w swoje działanie i stałą obserwację rynku. Dla nich warunki rosnących oczekiwań to nie zagrożenie, ale mnogość szans skutecznego funkcjonowania. Pierwszym i najważniejszym punktem odniesienia będą zawsze oczekiwania klientów.

Jednak dzisiejszy klient nie oczekuje już wyłącznie samego produktu doskonałej jakości. Chce znacznie więcej, chce ciągłego zainteresowania, ale pragnie również stałej stymulacji do działania. Jednak wielość produktów będących w stosunku do siebie substytutami powoduje, że klienci bardzo często mają poważne trudności w wybraniu jednej właściwej oferty i pozostanie jej wiernymi - dlatego właśnie, między innymi, spada współczynnik klientów lojalnych. Z drugiej strony firmy starają się podjąć absolutnie wszystkie możliwe działania zmierzające ku temu, by lojalność klienta kreować. Doskonale bowiem zdają sobie sprawę z tego, jaką wartością jest klient lojalny. Stanowi on źródło wiedzy o produktach firmy, którą to wiedzą bardzo chętnie dzieli się z organizacją, to w końcu on i jego zachowanie, potrzeby, oczekiwania wskażą dalsze ścieżki rozwoju firmy. Staje się on najlepszym medium przekazującym wiedzę o produkcie, jego użyteczności, wartościach rynkowych, inspirując tym samym innych klientów do działania.

Dlatego właśnie firmy tak chętnie podejmują zabiegi komunikacyjne mające na celu kreowanie lojalności klienta. Musimy jednak pamiętać, iż to starania długookresowe i nastawione nie tylko na zmianę dotychczasowych postaw klienta, 
ale przede wszystkim na zbudowanie silnego podłoża emocjonalnego, które połączy klienta z firmą/marką. Rynek pokazuje jednak, że samo zaangażowanie w standardowe działania komunikacyjne to odrobinę za mało z punktu widzenia klienta. Oczekuje on realnego zainteresowania firmy problemami istotnymi nie tylko dla niego, ale coraz częściej dla całego społeczeństwa.

Doskonale w te oczekiwania wpisuje się Corporate Social Responsibility (CSR). Bardzo dynamiczny rozwój tego typu działań, kreatywność ich rozwiązań oraz skuteczność potwierdzona przykładami rynkowymi powodują, że świetnie wpisują się one właśnie w działania skupione na kreowaniu lojalności klienta. Świeżość problematyki oraz jej dynamika spowodowały, iż kwestia ta stała się tematem niniejszego wywodu.

Celem ma być wskazanie, w jaki sposób firmy budują relacje lojalnościowe z klientem, wykorzystując działania właśnie z zakresu CSR. Rozważania teoretyczne uzupełnione zostaną o obserwacje własne autorki, czyli studia przypadków firm, które prowadzą działania z zakresu CSR i, co więcej, traktują je jako stały element swoich poczynań rynkowych.

\section{CSR, czyli czym jest społeczne zaangażowanie biznesu}

Obserwując rzeczywistość gospodarczą zauważymy, że coraz więcej firm deklaruje swoje silne zaangażowanie w problemy społeczne rynków, na których funkcjonują i co najważniejsze komunikują to w sposób, który jasno pokazuje, iż nie jest to tylko chwilowa moda, ale odpowiedzialne działanie mające na celu niemal całkowite uporanie się z danym problemem. Popularność społecznej odpowiedzialności firmy (CSR) w dzisiejszym świecie biznesu można tłumaczyć przede wszystkim rosnącą presją ze strony interesariuszy i opinii publicznej ${ }^{1}$.

Czym więc jest CSR? Pojęcie to okazuje się bardzo kontrowersyjne z punktu widzenia jego zdefiniowania. Pojawia się wiele głosów, które optują za ujęciem działań CSR jako tych, które wchodzą wyłącznie w skład narzędzi komunikacyjnych firmy, dla innych z kolei jest to konkretna strategia firmy, a może i nawet cała filozofia zarządzania nią, wyznaczająca dalsze kroki działania podejmowane przez daną organizację. Wśród sceptyków znajdują się i tacy, którzy CSR postrzegają wyłącznie jako fanaberie firmy obliczoną na chwilowy i, ich zdaniem, bardzo ulotny efekt. Dlatego właśnie uzasadnione wydaje się pochylenie nad różnorodnymi podejściami do tego pojęcia. Według Wikipedii CSR, to koncepcja, w której przedsiębiorstwa na etapie budowania strategii dobrowolnie

${ }^{1}$ G. Aniszewska, CSR a kultura organizacyjna, „Marketing i Rynek” 2010, nr 12. 
uwzględniają interesy społeczne i ochronę środowiska, a także relacje z różnymi grupami interesariuszy. Zgodnie z tym podejściem, bycie odpowiedzialnym nie oznacza tylko spełniania przez organizacje biznesowe (przedsiębiorstwa) wszystkich wymogów formalnych i prawnych, ale oprócz tego również zwiększone inwestycje w zasoby ludzkie, w ochronę środowiska i relacje z interesariuszami, którzy mogą mieć faktyczny wpływ na efektywność działalności gospodarczej tych organizacji oraz ich innowacyjność. Zatem wydatki tego rodzaju należy traktować jako inwestycję i źródło innowacji, a nie jako koszt, podobnie jak w przypadku zarządzania jakością². Komisja Europejska definiuje CSR jako styl zarządzania przedsiębiorstwem polegający na włączaniu kwestii społecznych, środowiskowych, etycznych i dotyczących praw człowieka do działań biznesowych i strategii, we współpracy z interesariuszami ${ }^{3}$. Definicja CSR wg ISO Guidance Standard on Social Responsibility - ISO 26000: 2010 to odpowiedzialność organizacji za wpływ jej decyzji i działań na społeczeństwo i środowisko, poprzez przejrzyste i etyczne zachowanie, które przyczynia się do zrównoważonego rozwoju, włączając zdrowie i dobrobyt społeczeństwa, uwzględnia oczekiwania interesariuszy (osób lub grup, które są zainteresowane decyzjami bądź działaniami organizacji), jest zgodne z mającym zastosowanie prawem i spójne $\mathrm{z}$ międzynarodowymi normami zachowania oraz wprowadzone $\mathrm{w}$ całej organizacji i praktykowane w jej działaniach w obrębie jej strefy wpływów ${ }^{4}$.

Przedsiębiorstwo, które planuje wdrożenie działań z zakresu CSR, musi mieć świadomość, iż staje przed poważnym wyzwaniem, ponieważ jest to droga, z której nie ma odwrotu. Firma może zająć się realizowaniem działań CSR w czterech głównych obszarach:

1. Rynek. Tutaj interesariuszami są konkurenci, klienci, czasem również dostawcy. Firma swoim działaniem rozwija całą branżę, sektor. Podnosząc standardy, podnosi jednocześnie świadomość marek.

2. Miejsce pracy. Działania są tym razem kierowane w stronę pracowników. Komfort ich pracy przekłada się nie tylko na jakość, motywację, ale i ogólne wrażenie o firmie. Lojalny pracownik pomoże nam zbudować lojalnego klienta.

3. Społeczeństwo. Celem działań tu podejmowanych jest przede wszystkim poprawa jakości życia, ale i bezpieczeństwa społeczeństwa.

4. Środowisko. Nurt zielonego marketingu jest bardzo silny. Rosnąca świadomość ekologiczna powoduje, iż sami klienci skupiają się w swoich poszuki-

${ }^{2}$ http:/www.pl.wikipedia.org/wiki/Spo $\%$ C5 $\% 82$ eczna_odpowiedzialno $\% \mathrm{C} 5 \% 9 \mathrm{~B} \% \mathrm{C} 4 \% 87$ biznesu [dostęp: 30.04.2013].

${ }^{3} \mathrm{http} / / /$ www.asbiznesu.pl/index.php?option=com_content\&view $=$ article\&id $=51 \&$ Itemid $=72$ [dostęp: 21.03.2013].

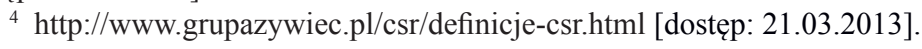


waniach produktów na markach, które dbają o ekologię i czynią z tego swój atut.

Tym, co jest wspólne dla wszystkich definicji CSR i obszarów, w jakich może być on wykorzystywany, jest podkreślenie w nich roli, jaką odgrywają interesariusze i jak ważne jest to działanie z punktu widzenia nie tylko interesu firmy, ale i ich właśnie.

Dlatego tak znacząco istotne wydaje się odpowiednie kreowanie kontaktów z klientami. To dzięki takiemu dialogowi można w jasny i bardzo naturalny sposób komunikować wartości i cele organizacji, a przecież CSR składa się między innymi właśnie na system wartości danej organizacji. Niezbędne wydaje się więc połączenie CSR z CRM. Te dwie filozofie skupione wokół jednego celu, jakim, w przypadku tego wywodu, jest kreacja lojalności klienta, wydają się optymalnymi sposobami jego osiągania. Co więcej, społeczne zaangażowanie biznesu nie mogłoby funkcjonować na optymalnym poziomie, gdyby właśnie nie zarządzanie relacjami. To dzięki temu organizacja ma szasnę poznać dokładnie interesariuszy oraz wyselekcjonować problemy, które są najbardziej dotkliwe społecznie.

\section{Wykorzystanie Customer Relationship Management}

Customer Relationship Management (CRM) najczęściej używany jest w znaczeniu terminu informatycznego, odnoszącego się do oprogramowania pozwalającego firmie prowadzić interakcje z klientami w sposób zorganizowany i ciągły. Pracownicy firmy dzięki tej technologii mają dostęp do informacji na temat dotychczasowych zachowań klienta, jego zakupów, preferencji, wymagań Spójrzmy jednak na CRM przez pryzmat jego roli w kreowaniu trwałych, opartych na zaufaniu i lojalności kontaktów z klientem. CRM to strategia biznesowa, polegająca na takim dobieraniu i zarządzaniu klientami, aby optymalizacja ich wartości była możliwa w długim okresie. Wymaga zaadaptowania filozofii i kultury skupionej na kliencie, co wspiera skuteczne procesy marketingu, sprzedaży i obsługi klienta. Aplikacje CRM mogą wesprzeć efektywne zarządzanie relacjami z klientami, pod warunkiem, że firma ma właściwe przywództwo, strategię i kulturę ${ }^{6}$. To, co łączy definicje CRM i wcześniej przytoczone definicje CSR, to przede wszystkim pojęcie osoby klienta i wskazanie na to, jak niezmiernie istotne dla funkcjonowania firmy jest odpowiednie zachowanie w stosunku do niego. Dodatkowo podkreśla się długofalowość działań wykorzystujących CRM i CSR.

\footnotetext{
${ }^{5}$ www.masterplan.com.pl [dostęp: 21.03.2013].

${ }^{6}$ www.CRMGuru.com [dostęp: 21.03.2013].
} 
Filozofia Customer Relationship Management ustawia marketing, rozumiany jako zarządzanie popytem, w roli kreatora całej działalności danej organizacji. Któż, jak nie osoby odpowiedzialne za sterowanie naszym rynkiem, jest predysponowany do określenia, jakie produkty i komu oferować, w jaki sposób zwiększyć lojalność klientów i jak dotrzeć do nowych. Dlatego właśnie marketing powinien mieć informację, która pozwoli obsłużyć każdego klienta indywidualnie, zapewnić mu komfort i poczucie bezpieczeństwa ${ }^{7}$. Jednocześnie należy tu wspomnieć o bardzo ważnym aspekcie wykorzystywania CRM w praktyce.

Zaleta CRM polega na tym, że nie jest zarezerwowany wyłącznie dla korporacji o poważnych zasobach finansowych, które mogą przeznaczyć na inwestycje w nowoczesne systemy informatyczne. Niekwestionowanym walorem CRM jest fakt, iż może go stosować każdy, kto zdaje sobie sprawę z tego, jak ogromną rolę on odgrywa. Gdzie w CRM jest miejsce na CSR? Okazuje się, iż CSR może pełnić wiele funkcji w ramach zarządzania firmą opartego na budowaniu relacji z klientem. Podstawą funkcjonowania CRM jest tworzenie baz danych klientów i zarządzanie nimi w sposób, który gwarantuje kreowanie silnych związków. To właśnie one stanowią podstawę późniejszych kontaktów firma - klient. Jak już wcześniej wspomniano, CSR ma na celu wspomóc budowanie odpowiednich relacji (m.in. lojalnościowych) z klientami poprzez, z jednej strony, zaangażowanie samej firmy, z drugiej, zaangażowanie klienta w pewną aktywność.

Należy bowiem pamiętać, iż CSR inicjowany przez daną organizację w ujęciu relacyjnym powinien wywoływać reakcję u swoich adresatów. Reakcja ta wielokrotnie polega na czynnym ich współuczestniczeniu w konkretnych kampaniach. Jednym z przykładów tego typu działania może być coroczna akcja marki Żywiec „Posadź dalej” w ramach programu „Po stronie natury”. To unikatowy wieloletni sojusz liderów z różnych sektorów na rzecz przyrody. W ramach programu od roku 2009 z powodzeniem współpracują ze sobą instytucja państwowa - Lasy Państwowe, organizacja pozarządowa - Fundacja Nasza Ziemia oraz organizacja biznesowa - Żywiec Zdrój SA. Każda ze stron wnosi do niego wyjątkową wiedzę, doświadczenie i wkład praktyczny lub finansowy. W ramach „Po stronie natury” organizowana jest coroczna akcja sadzenia miliona drzew w Beskidzie Żywieckim oraz ogólnopolski konkurs grantowy na projekty ekologiczne odpowiadające na potrzeby lokalnych społeczności. W pierwszych dwóch latach program funkcjonował pod nazwą „Moje silne drzewo”. Zadaniem „Po stronie natury” jest zwrócenie uwagi Polaków na problem ochrony środowiska naturalnego i potrzebę dbania o nie. Do programu może przyłączyć się każdy, kto chce zrobić coś dobrego dla przyrody i dobrze się przy tym bawić. Dotychczasowe działania przyczy-

\footnotetext{
${ }^{7}$ M. Zachara, CRM i nowoczesny marketing, ,Modern Marketing” 2000, nr 3.
} 
niły się procesu odnawiania Puszczy Karpackiej - 4 milionami drzew obsadzono obszar o powierzchni ponad 715 ha. W ramach konkursu grantowego, łącznym nakładem ponad pół miliona złotych dofinansowano do tej pory 89 projektów proekologicznych ${ }^{8}$. Należy pamiętać, iż program ten opiera się na bardzo poważnym zaangażowaniu klientów. Są to kampanie o charakterze społecznym, w których znane postaci, np. Sebastian Karpiel-Bułecka, zapraszają do współuczestniczenia w nich informując, jak ogromny wpływ na ekologię będzie miało zachowanie klienta i jego decyzja zakupowa. W efekcie wybierając produkt dana osoba staje się częścią czegoś naprawdę ważnego i ma poczucie, że pieniądze są reinwestowane w środowisko, tym samym ona sama przyczynia się do jego ratowania. Taki element współtworzenia pewnych niezwykle istotnych wartości powoduje, iż klienci czują się bardzo dobrze, co więcej, bardzo pozytywnie odbierają firmę, która angażuje ich w tego rodzaju działania - mają poczucie, że firma faktycznie o nich dba i to długofalowo, a do tego, co ważne, nie jest nastawiona wyłącznie na generowanie zysku. CSR daje bowiem możliwość tworzenia przeżyć i jako taki stanowi doskonałe podłoże do relacji lojalnościowych. Tego typu działania podejmowane przez firmy w większości wypadków nie są wyłącznie efektem mody na działania prospołeczne, ale ważnym elementem strategii firmy. Posiadanie lojalnych klientów, w dłuższym okresie warunkuje często obecność firmy na rynku.

Problem wielu firm nadal polega na braku umiejętności odnalezienia się na rynku globalnym. To właśnie, między innymi, dla nich gwarantem sukcesu może stać się wykorzystanie CSR jako działań o charakterze lokalnym, jednak wpływających na rynek globalnie. Szczególnie w początkowym etapie mającym na celu inicjowanie kontaktów z klientem działania takie są niezwykle ważne, a inwestycja w nie wydaje się nieodzowna.

Mimo że wydaje się to tak oczywiste, nadal na rynku polskim funkcjonują firmy nie aplikujące CSR do swoich strategii. Dlaczego działania te wydają się przez wielu postrzegane jako zarezerwowane wyłącznie dla gigantów rynkowych? Niestety, jedną z przyczyn może być specyfika samego klienta. Okazuje się bowiem, iż mimo rosnącej świadomości klienta, nadal dokonując wyborów kieruje się on nieco innymi kryteriami, aniżeli byśmy sobie tego życzyli. Przybliżmy więc ten problem na przykładzie polskiego klienta.

1. Nadal jeszcze nie zawsze dba on o to, kto mu sprzedaje produkt. Zwraca uwagę przede wszystkim na cenę, a nie na jakość produktu. Nie oznacza to jednak absolutnie, iż firmy pozostawiają ten problem samemu sobie. Klient ma mieć poczucie jak duże znaczenie dla otaczającego go świata mają jego własne codzienne decyzje zakupowe, a cena musi być zrównoważona jakością.

${ }^{8}$ http://www.zywiec-zdroj.pl/\#/4X0X [dostęp: 10.02.2013]. 
2. Niestety tylko nieliczni konsumenci wybierają towary lub usługi kierując się miejscem ich pochodzenia. Czyli kierują się tym, czy np. firma, która je produkuje:

- jest uczciwa, dba o klienta?

- troszczy się o ochronę środowiska?

- czy nie popada w konflikt z prawem?9

Optymistyczne jest to, iż globalnie klienci coraz chętniej kupują produkty lokalne, co więcej, firmy starają się wskazywać na korzyści jakie płyną właśnie $\mathrm{z}$ takich wyborów nie tylko dla klienta, ale i rozwoju całego rynku. Co istotne, kampanie relacyjne $\mathrm{z}$ naciskiem na etyczne aspekty funkcjonowania organizacji zaczynają przynosić efekty. Etyka zaczyna mieć dla klienta znaczenie, niestety nie stanowi jeszcze głównej determinanty wyboru. Dla odmiany, w wysoko rozwiniętych społeczeństwach konsumenci nie kierują się tylko jakością i ceną towaru, lecz istotny jest dla nich także kontekst działalności danej firmy.

Mimo specyfiki polskiego klienta absolutnie nie należy odrzucać idei kreowania z nim relacji lojalnościowych za pomocą CSR. Co więcej, reprezentowane przez niego postawy dają pole do działania. Może być to niezwykle inspirujące dla firm. Skoro rośnie jego świadomość społeczna, należy przede wszystkim robić wszystko, aby oprawa komunikacyjna, skupiona wokół lojalności, opierała się także na CSR. Jak łatwo można zaobserwować, CSR, szczególnie profesjonalnie przygotowany, świetnie radzi sobie z kreowaniem zainteresowania klienta, podtrzymaniem go i w efekcie wypracowaniem jego lojalności.

Jako przykład firmy, która od samego początku wejścia na rynek polski stara się komponować swoje strategie właśnie z narzędzi CSR warto przytoczyć markę IKEA. IKEA przenosi swoje dotychczasowe doświadczenia z innych rynków na rynek polski. Pewne schematy zachowań klientów na całym świecie są bardzo podobne. Klienci IKEA lubią otaczać się ładnymi funkcjonalnymi meblami. To osoby młode, aktywne, dynamiczne, lubiące zmiany i nowości. Taki jest klient IKEA. Firma jednak doskonale zdaje sobie sprawę, iż mimo pewnych podobieństw pomiędzy klientami na całym świecie istnieje między nimi również bardzo wiele różnic, które wpływają na ich postępowanie nabywcze.

Jednak niezmiernie istotnym elementem na całym świecie w tej chwili jest nurt proekologiczny i fakt jak ogromną rolę może wywrzeć na wzajemne relacje firma - klient. Działanie proekologiczne to działanie na rzecz społeczności globalnej, ale także lokalnej. To przekazanie informacji klientowi - dbamy o ciebie, bo jesteś dla nas ważny - co więcej, zależy nam na twoim długookresowym szczęściu, dlatego ekologia jest dla nas ważna. IKEA angażuje się w działanie

${ }_{9}$ E. Nowińska, Sponsoring trwaty i dojrzały, „Press” 1999, nr 1. 
na rzecz ekologii, przygotowując program „ekodomek - centrum segregacji”, jednocześnie wspiera sferę społeczną sponsorując tzw. ekolekcje. Edukowanie od najmłodszych lat powoduje, iż świadomość klientów rośnie wraz z nimi, a dzieci przenoszą rozwiązania, o których dowiedziały się podczas takich lekcji, na zachowania domowe, tym samym inspirując całą rodzinę do konkretnych postaw. Połączenie marki z kreowaniem odpowiednich zachowań i, co najważniejsze, wskazanie, iż wartości, które przekazuje IKEA, są dla marki ważne, jest optymalnym rozwiązaniem. To właśnie takie działania uwiarygodniają firmę w oczach klienta.

Wracając do kooperacji CRM i CSR, wydaje się, że aby dobrze i świadomie zarządzać relacjami z klientami i przekazywać im komunikaty, które stworzą w nich konkretne postawy oparte na lojalności w stosunku do marek, wystarczy słuchać tego, co sami chcą nam powiedzieć. Nie można jednocześnie zapominać o bardzo ważnym aspekcie całej sprawy. O ile tradycyjna orientacja marketingowa koncentruje się głównie na relacjach z nabywcą, to już współczesna orientacja marketingowa uwzględnia wagę całokształtu relacji firmy z różnymi podmiotami otoczenia. Obok nabywców ważną rolę w zakresie skuteczności działania firmy odgrywają bowiem dostawcy, odbiorcy nabywców, konkurenci oraz inne podmioty kształtujące reguły gry na rynku ${ }^{10}$. Jak więc budować te relacje oparte na kreowaniu lojalności?

\section{Proces budowania lojalności klienta}

Związek między zadowoleniem a lojalnością i pozostaniem klienta ma bardzo luźny charakter. Zadowolenie to poczucie klienta, że jego oczekiwania zostały spełnione. Ze wskaźników zadowolenia niestety nie wynika, jak wysokie (niskie) były te oczekiwania. Samo zadowolenie jest co prawda warunkiem lojalności, ale jej niestety nie gwarantuje. O ile zadowolenie jest poczuciem, to już lojalność jest zbiorem zachowań, które wiążemy z ponownym zakupem produktu lub usługi, zakupem innych produktów firmy, rekomendowaniem firmy innym.

Najbardziej przyziemnym celem niemal wszystkich działań prolojalnościowych jest przywiązanie klienta do marki po to, by rzadziej sięgał po produkty konkurencji, ale, co najważniejsze - należy budować emocje i przeżycia, to one bowiem stanowią bazę lojalności. Takie spojrzenie niestety jest proste i bezużyteczne. Sedno bowiem tkwi w umiejętnym przeprowadzeniu konsumenta przez pewien proces, który spowoduje zmianę charakteru jego relacji z nasza marką ${ }^{11}$.

${ }^{10}$ K. Fonfara, Marketing partnerski na rynku przedsiębiorstw, PWE, Warszawa 1999.

11 J. Otfinowski, Po szczeblach drabiny lojalności, „Marketing Serwis” 1999, nr 6. 
Zaczynamy od chwili, kiedy klient po raz pierwszy spotyka się z marką - nie wie o niej prawie nic, nie uświadamia sobie korzyści, jakie mógłby odnieść w wyniku jej zakupu, jednym słowem nie ma jeszcze powodu, dla którego miałby podjąć decyzję o jej nabyciu. Takiego klienta nazywamy zazwyczaj ,podejrzanym”. To etap, na którym firmy najczęściej wykorzystują klasyczne środki komunikacji. To doskonały moment, by już poinformować klienta o działaniach CSR podejmowanych przez firmę. Kolejny etap to „kandydat”. To stadium, w którym zaczyna się stosować w stosunku do klienta działania BTL. Na tym etapie firmy najczęściej rozpoczynają „rekrutację”. Te działania mogą, ale nie muszą, przynieść oczekiwany efekt, dlatego tak ważne jest dobre przygotowanie tego etapu, gdyż to właśnie on zadecyduje o powodzeniu całości programu. Chętnie wykorzystywany jest tu sampling, chodzi bowiem o to, aby klient spróbował naszego produktu. Perfekcyjna informacja o zaangażowaniu w CSR wzbogaca próbkę, nadając jej wymiar wyjątkowej. Proces „rekrutacji” powinno wieńczyć podanie przez klienta danych, które pomogą w stworzeniu bazy wykorzystanej później w celu nawiązania i utrzymywania kontaktów. Kolejny etap to „nabywca”, czyli ktoś kto już kilkakrotnie spróbował lub kilkakrotnie kupił nasz produkt, ale niestety nadal podatny jest na działanie konkurencji. Chętnie stosowanym narzędziem jest tutaj program zbierania punktów. Niestety bardzo często uważa się tego typu działania za formę nacisku czy wręcz próbę przekupienia klienta. Jednak jeśli jest to częścią większego projektu, czyli chodzi np. o recycling opakowań po przesłaniu ich do firmy, a przy okazji możliwość uzyskania nagrody - wtedy klienci uczestniczą bardzo chętnie w tego typu akcjach.

Jeśli dotychczasowe działania zakończyły się pomyślnie, mamy do czynienia z „użytkownikiem”, czyli osobą wykazującą pewną lojalność, a sama marka stała się już istotnym elementem codziennego życia. Jednym ze sposobów kontaktu z klientem na tym poziomie jest wydawanie przez firmy biuletynów, specjalnie dla swoich klientów. Kiedy jesteśmy już pewni, że „użytkownik” jest pozytywnie związany z nasza marką, możemy podjąć próbę wykorzystania go do rekrutacji kolejnego pokolenia „nabywców”, staje się on naszym „adwokatem”, czyli osobą, dla której dana marka jest niezwykle istotna, a podejmowane przez nią inicjatywy stają się częścią stylu życia klienta. Jednak to nie oznacza, że cały proces już zakończyliśmy. To dopiero początek - teraz bowiem rozpoczynamy najtrudniejszy i najbardziej wymagający zaangażowania okres utrzymywania lojalności klientów. Doświadczeni praktycy wiedzą bowiem, iż nie tyle samo zbudowanie lojalności klienta jest trudne, ile jej utrzymanie. Dlatego właśnie tak ogromną uwagę zwraca się na potrzebę stałego kontaktu między firmą a klientem. Gdzie jest miejsce na CSR? Właściwie na każdym etapie pozyskiwania lojalności klienta, na każdym z nich bowiem odgrywa on poważną rolę w kreowaniu emocji klienta. 
Jedną z akcji budowania lojalności klientów opartą na CSR jest akcja Procter $\&$ Gamble-producenta pasty do zębów Blend-a-med. Blend-a-med wykorzystuje bardzo popularną obecnie strategię kreowania lojalności poprzez edukację i własne poważne zaangażowanie w zdrowie klienta. Od 1993 roku Bled-a-med jest oficjalnym twórcą ogólnopolskiego programu edukacyjnego, przygotowywanego przy współpracy Polskiego Towarzystwa Stomatologicznego i Fundacji Promocji Zdrowia Jamy Ustnej. Również od tego samego roku sponsoruje szkolny program edukacyjny na temat higieny jamy ustnej. Wszyscy doskonale znamy busy Blend-a-med, czyli tzw. gabinety stomatologiczne na kółkach. Pierwsze busy wyjechały w kierunku małych miejscowości, gdzie dzieci maja ograniczony dostęp do stomatologa. Każde z dzieci zostało poddane badaniu stomatologicznemu, ale również każde otrzymało prezenty od Blend-a-med w postaci szczoteczki i pasty do zębów. Po pewnym czasie, kiedy całą akcję nagłośniono w mediach, wszystkie dzieci już doskonale znały kolorowe busy stomatologiczne, kojarzyły je z zabawą, miłą załogą na ich pokładzie. Tym samym Blend-a-med udało się osiągnąć kilka celów. Przede wszystkim minimalizowano opór psychiczny dzieci przed wizytami u stomatologa, utrwalano wizerunek marki, a co najważniejsze - każde dziecko kojarzyło pastę Bled-a-med jako swoja pastę, tym samym gościła ona w większości polskich domów. Pozytywne skojarzenia z produktem są niezmiernie istotnym czynnikiem w kreowaniu długookresowych związków. Blend-a-med to także oficjalny twórca wortalu „Zdrowy uśmiech”.

Konkludując, firmy kreując program CSR, którego celem miałoby być aranżowanie lojalności klienta, osiągają wiele celów szczegółowych:

- kształtowanie dobrej reputacji,

- polepszenie relacji klienta z firmą,

- zwiększenie wielkości zamówienia,

- zwieszenie częstotliwości zakupów,

- przeciwdziałanie zmianie marki,

- przyciąganie nowych klientów,

- utrzymanie klientów już posiadanych,

- osłabienie pozycji konkurencji,

- wprowadzenie nowej strategii firmy.

Realizacja każdego z tych zadań przyczynia się do optymalizacji efektu głównego, jakim jest właśnie lojalność - czyli stan długookresowej świadomości firmy/marki, jej wartości, cech, poczucia bezpieczeństwa transakcji i przede wszystkim maksymalnego zadowolenia.

Cel wymieniony jako pierwszy możemy uznać za cel priorytetowy, ponieważ osiągnięcie pozostałych jest uzależnione właśnie od niego. Wykorzystanie CSR 
na wstępnym etapie, czyli edukacji klienta, wykreowania pozytywnych skojarzeń z firmą powoduję, iż szanse na wybór produktu takiej właśnie firmy spośród oferty rynkowej rosną ${ }^{12}$.

Złożoność wzajemnych relacji pomiędzy wszystkimi niemal czynnikami otoczenia firmy zarówno wewnętrznego, jak i zewnętrznego wymaga podjęcia szybkich i zdecydowanych działań mających na celu dostosowanie się do zmieniających się warunków. Powyżej opisane relacje powodują, iż śmiało możemy stwierdzić, że marketing wkracza w nowa erę - czas, który będzie wymagał od niego z jednej strony ogromnych nakładów, głównie intelektualnych, z drugiej strony jednak gwarantował mu skuteczność i efektywność dokonanych posunięć. Jak ważne są działania z zakresu CSR i, co więcej, jak bardzo są prestiżowe, świadczyć może chociażby doroczny ranking ranking odpowiedzialnych firm publikowany przez „Dziennik Gazetę Prawną”. Od 2007 roku tworzą go dr Bolesław Rok z Centrum Etyki Biznesu Akademii Leona Koźmińskiego - odpowiedzialny za merytoryczną stronę rankingu - oraz Jarosław Horodecki, zajmujący się analizą danych i przygotowaniem finalnych zestawien. Patronem rankingu odpowiedzialnych firm jest Forum Odpowiedzialnego Biznesu, za weryfikację zaś odpowiada firma konsultinowa PwC. Lista 10 najlepszych w rankingu odpowiedzialnych firm w 2013 roku:

1. GlaxoSmithKline Pharmaceuticals SA, GK

2. Kompania Piwowarska SA

3. Nutricia

4. Danone Sp. z o.o.

5. PKN Orlen SA

6. Schenker Sp. z o.o.

7. Tesco Polska sp. z o.o.

8. Grupa Lotos SA

9. Orange Polska (d. TP SA)

10. Toyota Motor Manufacturing Poland sp. z o.o. ${ }^{13}$

Ranking ten pokazuje, iż CSR to działania, bez których wiele firm nie wyobraża sobie swojego funkcjonowania, możemy nawet pokusić się o stwierdzenie, że CSR stanowi bardzo poważny czynnik ich sukcesu. Co ważne, firmy te należą do grona firm najbardziej wartościowych oraz tych, które posiadają grono naprawdę lojalnych klientów.

${ }^{12}$ A.A. Grey, K. Skildum-Reid, The Sponsor's Toolkit, McGraw-Hill Australia Pty Ltd, Roseville 2001.

${ }^{13} \mathrm{http}$ //www.csrinfo.org/pl/wiadomosci/informacje-prasowe/4463-znamy-wyniki-viiedycji-rankingu-odpowiedzialnych-firm [dostęp: 24.04.2013]. 


\section{Zakończenie}

CSR to działania, o których żadna firma skupiona na własnym rozwoju, ale przede wszystkim rozwoju całego rynku, nie powinna zapominać. To, jak ważny jest dziś klient i jak nieocenione jest jego zaangażowanie w tworzenie marek wie każdy odpowiedzialny przedsiębiorca i właśnie dlatego niezwykle cenne jest umiejętne kreowanie relacji poprzez wspólne pochylenie się nad poważnymi problemami dotyczącymi rynku, na którym firma funkcjonuje. Klient zaangażuje się we wspólne działanie wtedy, kiedy poczuje silną więź z firmą inspirującą go do tego działania. Musi poczuć, że jest dla niej niezwykle istotny, a jego głos faktycznie ma znaczenie. Cel ten można osiągnąć poprzez zaangażowanie się firm w działalność CSR. Związana może być ona z miejscem pracy, rynkiem, środowiskiem naturalnym i społecznością lokalną i, w zależności od tego jak bardzo świadoma swojej roli jest firma, może dotyczyć wszystkich tych obszarów lub wyłącznie wybranych. Praktyka rynkowa pokazuje, że firmy decydujące się na CSR podchodzą do tego w sposób bardzo poważny, wplatając te działania do całego obszaru strategicznego, co oczywiście komunikują na rynku. Badanie przeprowadzone przez Universum Topical Report w 2010 roku pokazało, iż Europejczycy na pierwszym miejscu stawiają działalność na rzecz rozwoju społeczności lokalnej, są też bardziej wyczuleni na problemy związane ze środowiskiem naturalnym ${ }^{14}$. Wskazuje to więc jasno, które obszary CSR zaniedbane pozostać nie mogą. To co ważne, to fakt, że CSR doskonale sprawdza się na każdym etapie kreowania lojalności klienta - stymulując go do działania, ale jednocześnie zmieniając jego postawy w stosunku do firmy. Lojalność ściśle związana jest z emocjami, CSR pozwala te emocje kreować, tym samym jego rola w kreowaniu lojalności klienta jest nieoceniona.

\section{Bibliografia}

Aniszewska G., CSR a kultura organizacyjna, „Marketing i Rynek” 2010, nr 12 Dąbrowska A., Janoś-Kresło M., Etyka działalności przedsiębiorstw a etyka postępowania konsumenta, „Marketing i Rynek” 2012, nr 1

Fonfara K., Marketing partnerski na rynku przedsiębiorstw, PWE, Warszawa 1999

${ }^{14}$ A. Dąbrowska, M. Janoś-Kresło, Etyka działalności przedsiębiorstw a etyka postępowania konsumenta, ,Marketing i Rynek” 2012, nr 1. 
Grey A.A., Skildum-Reid K., The Sponsor's Toolkit, McGraw-Hill Australia Pty Ltd, Roseville 2001

Nowińska E., Sponsoring trwaty i dojrzaty, „Press” 1999, nr 1

Otfinowski J., Po szczeblach drabiny lojalności, „Marketing Serwis” 1999, nr 6 Zachara M., CRM i nowoczesny marketing, „Modern Marketing” 2000, nr 3

http://www.asbiznesu.pl/index.php?option=com_content\&view=article\&id=51\& Itemid $=72$

http://www.CRMGuru.com

http://www.csrinfo.org/pl/wiadomosci/informacje-prasowe/4463-znamy-wynikivii-edycji-rankingu-odpowiedzialnych-firm

http://www.grupazywiec.pl/csr/definicje-csr.html

http://www.masterplan.com.pl

http://www.pl.wikipedia.org/wiki/Spo\%C5\%82eczna_odpowiedzialno\%C5\%9B $\%$ C4\%87_biznesu

http://www.zywiec-zdroj.pl/\#/4X0X 